\title{
INFLUENCE OF RADIATION LEVEL ON PLANT GROWTH, YIELD AND QUALITY OF ESSENTIAL OIL IN CARQUEJA
}

\author{
Influência do nível de irradiância no crescimento da planta, \\ rendimento e composição do óleo essencial em carqueja
}

\author{
Fabiano Guimarães Silva ${ }^{1}$, José Eduardo Brasil Pereira Pinto², Maria das Graças Cardoso ${ }^{3}$, \\ Evandro A. Nascimento ${ }^{4}$, David Lee Nelson ${ }^{5}$, Juliana de Fátima Sales ${ }^{6}$, Daniel José de S. Mol $^{7}$
}

\begin{abstract}
In this research it was studied the influence of the radiation intensity on growth and on the essential oil yield of Baccharis trimera. The plants growth was studied under four levels of radiation: 100, 60, 50 and 20\% during a 259-day long period. Plants were then evaluated for height, number of nodes, branches, stem diameter (at the height of the colon), biomass formation, and content and composition of the oil. The highest level of radiation caused increases in all of the variables evaluated, except for height, which was reduced with increasing radiation. Essential oil content also increased with increasing level of radiation.
\end{abstract}

Index terms: Baccharis trimera, Asteraceae, medicinal plant.

\section{RESUMO}

A influência do nível de radiância no crescimento da planta, rendimento e qualidade do óleo essencial de Baccharis trimera foi estudado neste trabalho. As plantas foram cultivadas sob 4 níveis de radiância: 100, 60, 50 e $20 \%$ durante um período de 259 dias. Foram avaliadas, quanto ao comprimento, número de nós, ramos, diâmetro do caule (altura do colo), acúmulo de fitomassa, conteúdo e composição do óleo essencial. O nível mais elevado de radiação causou aumento em todas as características avaliadas, exceto para o comprimento, que foi reduzido com o aumento na radiação. O rendimento de óleo essencial também aumentou com a elevação do nível de radiância.

Termos para indexação: Baccharis trimera, Asteraceae, planta medicinal.

(Recebido para publicação em 5 de junho de 2004 e aprovado em 28 de junho de 2005)

\section{INTRODUCTION}

Carqueja-amarga [Baccharis trimera (Less) D.C.] is utilized in the treatment of rheumatism, hepatobiliary disorders, diabetes, skin, ulceration and wounds (GENE et al., 1996). A number of studies reported that plants in this genus are potential sources of essential oil for the pharmaceutical and cosmetic industries (JAKUPOVIC et al., 1990; LOAYZA et al., 1995; QUEIROGA et al., 1996; SILVA \& GROTTA, 1971; SUTTISRI et al., 1994).

Plants in terrestrial habitats are exposed to number of pests, bacteria, fungi, viruses, nematodes, insects, and animals. Since the plants cannot defend themselves from these herbivorous and pathogens simply through movement, they need to be protect in other ways. In this defense process, in addition for example, terpenes or terpenoids (also called isoprenoids) to the cuticle and periderm, secondary plant compounds are utilized for defending against a variety of herbivores and pathogenic microorganisms (TAIZ \& ZEIGER, 1998). Secondary metabolic are often specific to a particular plant species or related to taxonomic groups of species whereas basic primary metabolism are found throughout the plant kingdom.

Studies on thyme (Thymus vulgaris L.) showed the effect of radiance on the stimulus to form trichomes. It is known that their formation is a pre-requisite for accumulation of essential oil in those plants, where the content of monoterpenes in a number of organs of seedlings was strictly correlated to trichome number (YAMAURA et al., 1989).

It has also been observed that plant grown under higher radiation intensity were shorter, had shoots with more tillers, and thicker branches on the shoot, while plants cultivated under less intense radiation, had a prostrate growth with thinner, broader leaves and a slightly pale green color. These morphological adaptations to radiation intensities favor a better light interception, resulting in greater dry biomass yields. A positive correlation was found between the number of oil-producing glands and the

1 Professor do CEFET - Rio Verde - GO - Laboratório de Cultura de Tecidos - Cx. P. 66 - fabiano@cefetrv.edu.br

${ }^{2}$ Professor Titular do Departamento de Agricultura - Universidade Federal de Lavras/UFLA - Cx. P. 3037-37.200-000 - Lavras, MG - jeduardo@ufla.br

${ }^{3}$ Laboratório de Química Orgânica - Departamento de Química - Universidade Federal de Lavras/UFLA - Cx. P. 3037 - 37.200-000 - Lavras, MG

${ }^{4}$ Instituto de Química/Universidade Federal de Uberlândia.

${ }^{5}$ FAFAR/Universidade Federal de Minas Gerais.

${ }^{6}$ Departamento de Biologia/Universidade de Rio Verde - FESURV - Rio Verde, GO - jfsales@fesurv.br

${ }^{7}$ Discente do curso de Agronomia - Universidade Federal de Lavras/UFLA - Cx. P. 3037 - 37.200-000 - Lavras, MG. 
essential oil content, suggesting that an increase of light intensity may increase the formation of oil-producing glands, with subsequent increases in essential oil content. The composition of essential oil was significantly affected by radiation levels (LETCHAMO et al., 1994; LETCHAMO \& GOSSELIN, 1995, 1996). Different levels of radiation presented distinct yields of essential oil in Lippia alba (Mill.) N.E., the maximum yield being obtained at the highest level of irradiation (VENTRELLA \& MING, 2000).

Practically all carqueja oil at present comes from gathering the plant from its native habitat that results in a heterogeneous oil production and to a likely extinction of that plant. It is necessary therefore, to cultivate the carqueja plant for commercial oil production. The objective of the present work was to evaluate the influence of radiation levels on growth and accumulation of essential oil, aiming at optimizing the oil yield without reducing its quality.

\section{MATERIAL AND METHODS}

\section{Plant material}

Seedling were raised from seeds collected in the Horto de Plantas Medicinais/Universidade Federal de Lavras, 94 days after planting in Plantmax ${ }^{\circledR}$ substrate in a greenhouse. Voucher species have been deposited in the Herbarium of the biology department of the Universidade Federal de Lavras under number 169933.

\section{Location of the experiment}

The experiment was conducted in the field from March 30 to December 13, 2000, at the Medicinal PlantHorticulture Sector/DAG of the Universidade Federal de Lavras, (latitude of $21^{\circ} 14$ 'S; longitude $45^{\circ} 00^{\prime}, \mathrm{GRW}$ ) at 918.87 meters altitude. The characteristics of the climate over the duration of the experiment are shown in Table 1.

\section{Radiation conditions}

Four radiation levels were evaluated, utilizing black nylon screens known commercially as "sombrite" screens with commercial specifications 80,50 and $30 \%$ which corresponded to $21.92 ; 50.36$ and $60.13 \%$ of irradiation, respectively, as messured by SKP 200 radiometer, mark HANSTECH and full sunshine (100\%). The experiment was established with the interrow spacing of $1.0 \times 0.5$ meters interplants. Irrigation was applied every other day for 30 minutes by a sprinker system.

\section{Evaluated characteristics}

Growth

At the end of 259 days, plants were harvested from
7 to $10 \mathrm{a}$. $\mathrm{m}$. and height, number of branches; number of nodes; diameter (at soil level); and the fresh and dry biomass of shoots and roots were measured.

\section{Extraction and determination of the essential oil yield}

The essential oil was separated by the steam distillation method. The aerial parts were harvested cut in small pieces $(5 \mathrm{~cm})$ and dried in a forced-air oven at a maximum temperature of $35^{\circ} \mathrm{C}$ to constant mass. A $100 \mathrm{~g}$ d.w. sample of biomass was transferred to a three-necked round-bottomed flask (1L in capacity) and steam distilled. The collected hydrolate was extracted four times with dichloromethane (total volume $290 \mathrm{ml}$ ), the organic fractions were combined and dried over anhydrous magnesium sulfate. The mixture was filtered and evaporated on a rotatory evaporator at a temperature of $40{ }^{\circ} \mathrm{C}$ and pressure of $200 \mathrm{~mm} \mathrm{Hg}$. The product was transferred to a glass flask and left in a oven at $35^{\circ} \mathrm{C}$ for complete evaporation of the dichoromethane. The mass of oil obtained was determined. The oil contend was multiplied by the total dry biomass, obtaining the yield of oil/plant.

\section{GC/MS analysis of the essential oil}

The chemical analyses of essential oils obtained were performed by Gas Chromatography coupled with Mass Spectrophotometry (GC/MS) on a QP 5000 apparatus (Shimadzu) equipped with a $30 \mathrm{~m}$ DB5 capillary column and a 1,400.000 spectra mass spectrum library (Wiley 140). A $60^{\circ} \mathrm{C}-240^{\circ} \mathrm{C}$ temperature program $\left(3{ }^{\circ} \mathrm{C} / \mathrm{min}\right.$ ramp, 240 ${ }^{\circ} \mathrm{C}$ plateau for 15 minutes) was used. The compounds were identified on the basis of the comparison of their mass spectra with those existing in the library with a KOVAT Index.

\section{Experimental design}

Experimental design was a randomized block with three replications each one having 10 plants. The results were analyzed using ANOVA procedure and Tukey's Test.

\section{RESULTSAND DISCUSSION}

\section{Growth}

Plant height of $B$. trimera decreased with increasing levels of radiation (Pd" 0.05 ) (Table 2). There were significant differences in the number of branches only between $20 \%$ and $100 \%$ radiation levels. Plants grown under $20 \%$ of radiation yielded a smaller number of branches than the plants cultivated in full sunshine and the other levels of 
radiation did not differ among one another. Similarly, the number of nodes were different only in plants cultivated at the $100 \%$ radiation level, from plants at the $20 \%$ radiation levels. The plants cultivated at $100 \%$ of radiation presented a shorter internode distance comparated to the plants grown at 20\%, even though, plants were taller with $20 \%$ radiation. Plants that received $20 \%$ level of radiation had a smaller stems diameter than plants grown at 50,60 or $100 \%$ radiation. The fresh and dry biomass yields of the aerial parts increased significantly with the rise in radiation level. Plant grown with $100 \%$ radiation dry matter accumulation was four times greater than those grown at 20\% radiation. The trend in the underground biomass yields was similar to that of the aerial portion. At $20 \%$ of radiation, plants had a lower biomass yield than plants at the $100 \%$ radiation while at the 50 and $60 \%$ radiation levels root biomass yields were similar.

The occurrence of a greater number of branches on B. trimera (carqueja-amarga) plants cultivated under high radiation levels was also observed in thyme (LETCHAMO \& GOSSELIN, 1996). Stem diameter may be a good indicator of the net assimilatory capacity of the plant (NAVES, 1993), which may account for the larger diameter found in plants cultivated at the highest radiation levels. An increase in the accumulation of shoot biomass with a rise in the radiation level indicates that $B$. trimera requires full sun for optimum yield. Similar results were observed in $B$. neglecta Britt. by Auken \& Bush (1990).

TABLE 1 - Average daily temperatures $\left(\mathrm{T}^{\circ} \mathrm{C}\right)$, total monthly rainfall $(\mathrm{P})$, average relative daily humidity $(\mathrm{RH})$ and average daily insulation (I) during the period of March 30, 2000 to December 13, 2000.

\begin{tabular}{|c|c|c|c|c|c|c|}
\hline \multirow[t]{2}{*}{ Months } & \multicolumn{3}{|c|}{$\mathbf{T}\left({ }^{\circ} \mathrm{C}\right)$} & \multirow[t]{2}{*}{$\mathbf{P}(\mathbf{m m})$} & \multirow[t]{2}{*}{ RH (\%) } & \multirow[t]{2}{*}{ I (h) } \\
\hline & Max. & Min. & Mean. & & & \\
\hline March & 27.89 & 17.66 & 21.84 & 192.8 & 78.77 & 6.14 \\
\hline April & 27.37 & 15.09 & 20.36 & 16.4 & 69.50 & 8.89 \\
\hline May & 25.09 & 12.19 & 17.71 & 4.1 & 70.00 & 8.39 \\
\hline June & 25.17 & 10.58 & 17.09 & 0.4 & 64.87 & 8.26 \\
\hline July & 23.96 & 10.50 & 16.03 & 9.2 & 65.58 & 7.09 \\
\hline August & 26.6 & 12.16 & 18.45 & 13.1 & 57.82 & 7.49 \\
\hline September & 25.53 & 14.58 & 19.11 & 109.9 & 71.53 & 5.73 \\
\hline October & 30.45 & 17.15 & 23.08 & 25.2 & 61.29 & 7.71 \\
\hline November & 26.88 & 17.05 & 21.14 & 239.2 & 76.47 & 5.20 \\
\hline December & 28.59 & 17.90 & 22.33 & $73.1^{\mathrm{Z}}$ & 72.85 & 7.05 \\
\hline
\end{tabular}

$\mathrm{z}$ until December 13, 2001.

TABLE 2 - Mean height, branch number, node number, stem diameter, biomass accumulation and content and yield of essential oil in carqueja-amarga (Baccharis trimera) at 259 days of cultivation at different radiation levels. Lavras, UFLA, 2001.

\begin{tabular}{|c|c|c|c|c|}
\hline \multirow[t]{2}{*}{ Evaluated characteristics } & \multicolumn{4}{|c|}{ radiation level (\%) } \\
\hline & 20 & 50 & 60 & 100 \\
\hline Height (m) & $1.84 \mathrm{~A}^{\mathrm{Z}}$ & $1.55 \mathrm{~B}$ & $1.47 \mathrm{BC}$ & $1.31 \mathrm{C}$ \\
\hline Branch number & $8.60 \mathrm{~B}$ & $9.69 \mathrm{AB}$ & $12.50 \mathrm{AB}$ & $14.30 \mathrm{~A}$ \\
\hline node number & $29.80 \mathrm{~B}$ & $33.73 \mathrm{AB}$ & $33.50 \mathrm{AB}$ & $34.50 \mathrm{~A}$ \\
\hline Stem diameter $(\mathrm{cm})$ & $1.19 \mathrm{~B}$ & $1.62 \mathrm{~A}$ & $1.56 \mathrm{~A}$ & $1.76 \mathrm{~A}$ \\
\hline Biomass - fresh aerial part (g) & $553.39 \mathrm{C}$ & $1258.87 \mathrm{~B}$ & $1245.47 \mathrm{~B}$ & $2172.57 \mathrm{~A}$ \\
\hline Biomass - dry aerial part (g) & $166.62 \mathrm{C}$ & $412.51 \mathrm{~B}$ & $455.54 \mathrm{~B}$ & $690.75 \mathrm{~A}$ \\
\hline Biomass - fresh root (g) & $26.57 \mathrm{C}$ & $88.38 \mathrm{~B}$ & $112.68 \mathrm{~B}$ & $207.88 \mathrm{~A}$ \\
\hline Biomass - dry root $(\mathrm{g})$ & $11.98 \mathrm{C}$ & $35.24 \mathrm{~B}$ & 49.92 B & $82.10 \mathrm{~A}$ \\
\hline Oil content $(\%)$ & $0.0358 \mathrm{~A}$ & $0.0342 \mathrm{~A}$ & $0.0460 \mathrm{~A}$ & $0.0591 \mathrm{~A}$ \\
\hline Oil yield (g/plant) & $0.0596 \mathrm{~B}$ & $0.141 \mathrm{AB}$ & $0.21 \mathrm{AB}$ & $0.408 \mathrm{~A}$ \\
\hline
\end{tabular}

Ciênc. agrotec., Lavras, v. 30, n. 1, p. 52-57, jan./fev., 2006 
Difference in the growth habit on plants grown at different radiation levels was also observed for thyme (LETCHAMO \& GOSSELIN, 1996). This difference is probably due to the great height of plants grown at $20 \%$ radiation $(1.84 \mathrm{~m})$, compared with the plants grown at $100 \%$ $(1.31 \mathrm{~m})$. Differences in the height of plants cultivated at different levels of radiation seem to contradict the results obtained for Baccharis neglecta Britt. (AUKEN \& BUSH, 1990). According to these results, significant increases in plant height were observed with increasing irradiation level, but, after verifying the intensities evaluated by those authors, one can conclude that they were reduced (from $53 \mathrm{~mm} \cdot \mathrm{m}^{-2} \cdot \mathrm{s}^{-1}$ to $611 \mathrm{~mm} \cdot \mathrm{m}^{-2} \cdot \mathrm{s}^{-1}$ ), insufficient to cause typical responses of height reduction. In the present were $B$. trimera plants were grown under a tropical climatic conditions and at a much higher radiation intensities around $1,270 \mathrm{~mm} \cdot \mathrm{m}^{-2} \cdot \mathrm{s}^{-1}$.

\section{Contend and yield of essential oil}

There was a non-significant trend to higher essential oil contend with increasing radiation levels (Table 2). The oil yield on per plant basis, however, increased significantly as the radiation level increased. Oil yield per plant was $0.0596 \mathrm{~g}$ of oil in plants grown at $20 \%, 0.141 \mathrm{~g}$ at $50 \%, 0.21 \mathrm{~g}$ at $60 \%$ and $0.408 \mathrm{~g}$ at $100 \%$ radiation.

The means of the essential oil contents were lower than those reported in previous studies with $B$. retusa D.C., (0.3\%) (SILVA \& GROTTA, 1971); $0.2 \%$ in $B$. articulata (Lam.) Pers., B. myrtilloides Griseb. and $B$. rufenses Spreng. (ZUNINO et al., 1998), 0.3\% in $B$. $\operatorname{articulata}$ (Lam.) Pers., and 0.3-0.1\% in B. trimera (Less) D.C. (SIQUEIRA et al., 1985). In addition to several factors, such as temperature, altitude, soil fertility, locality, harvest season, post-harvest physiological stage, extraction method and others, which may influence essential oil content, the intense rainy period of over 15 days during the harvest must also be mentioned. Water reduces the epicuticular wax content, thereby causing an increase in oil volatilization (LETCHAMO \& GOSSELIN, 1996) and this may have occurred in the present work. Thyme plants (LETCHAMO et al., 1994; LETCHAMO \& GOSSELIN, 1995, 1996) and Lippia alba (Mill.) N.E. (VENTRELLA \& MING, 2000), submitted to a higher radiation level, had their essential oil contents increased. This fact shows that different species respond in distinct manners to the radiation level in terms of essential oil production. Even though no increasing trend occurred in oil percentage with the increase in radiation level, the highly significant effect on biomass production and, consequently, in oil yield would be far higher at the highest radiation levels. In an attempt to estimate the total oil yield in this work, 20,000 plants/ha, would produce around $3,332 \mathrm{~kg} / \mathrm{ha}$ dry weight, yielding $1,193 \mathrm{~kg} / \mathrm{ha}$ of essential oil at the $20 \%$ radiation level. In full sunshine, $13,815 \mathrm{~kg} / \mathrm{ha}$ of dry biomass would be produced, which would yield about $8,164 \mathrm{~kg} / \mathrm{ha}$ of essential oil. This yield corresponds to an oil yield about seven times greater than that obtained from plants at the $20 \%$ radiation treatment.

\section{Analysis of the composition of essential oil by GC/MS}

The principal compound found in the three radiation levels was spathulenol (I), followed by epiglobulol (II) at $50 \%$ and $100 \%$, and by palustrol [ledum] (III) and epiglobulol at 20\% radiation (Table 3 and Fig. 1). The contents of spathulenol were similar, 28.47; 27.40 and 27.5\% for radiation levels, 20,50 and $100 \%$, respectively, while palustrol contents varied with the different radiation levels. The highest content $(11 \%)$ was obtained at the lowest level of radiation. At the 50 and $100 \%$, levels palustrol contend decreased respectively 4.67 and $4.68 \%$. Epiglobulol also varied at the different radiation levels. Similar values were obtained for the radiations level of 50\% (11.13\%) and $100 \%(11.10 \%)$. At $20 \%$ radiation the epiglobulol contend was $6.44 \%$. Aromadrendennepoxide I of 8.25 and $8.26 \%$ was detected at the 50 and $100 \%$ radiation levels, but only $4.77 \%$ at the lowest radiation level. Aromadendrennepoxide II was not found at 20\%, only at the height levels, $50 \%(3.01 \%)$, and $100 \%(8.26 \%)$, radiation levels. Similar results were obtained for globulol (IV), with contents of 2.14 and $2.11 \%$ at the levels of 50 and $100 \%$ radiation, respectively, and not detected at the $20 \%$ radiation. Other compounds were identified as: a-terpineol (V) and phytol (VI) (3.50 and 1.00\%), acetileugenol $(2.68 ; 2.62 ; 2.59 \%)$, viridifloral (VII) $(4.80,4.08$, $4.01 \%)$ and guaiol (VIII) $(4.29,5.23,5.26 \%)$, the first two compounds at 50 and $100 \%$ radiation levels and the last three with 20, 50 and 100\% radiation (Table 3 and Figure 1).

In addition to the variations in the individual ingredients in carqueja's essential oil due to variations in radiation intensities, different species of Baccharis may also have different concentrations of the individual ingredients. For example, in B. Salicifolia Pers., spathulenol and globulol concentrations respectively, 1.19 and $0.33 \%$ (LOAYZA et al., 1995). The same compound in B. articulata (Lam.) Pers., B. myrtilloides Griseb. and B. rufenses Spreng. were also detected respectively at concentrations of 2.0, 3.5 and $0.1 \%$. a-terpeniol was also found in these species, bu only in trace amounts, viz, less than $0.1 \%$ (ZUNINO et al., 1998). Spathulenol was also reported in the 
epicuticular wax of B. linearis (Ruíz \& Pav.) Pers. This dissipation of excess light and presents protection against compound presents anti-insecticide activity, causes desiccation (FAINI et al., 1999).

TABLE 3 - Gas Chromatography analysis of the essential oil of carqueja-amarga (Baccharis trimera) plants at 259 days of cultivation at different levels of radiation. Lavras, UFLA, 2001.

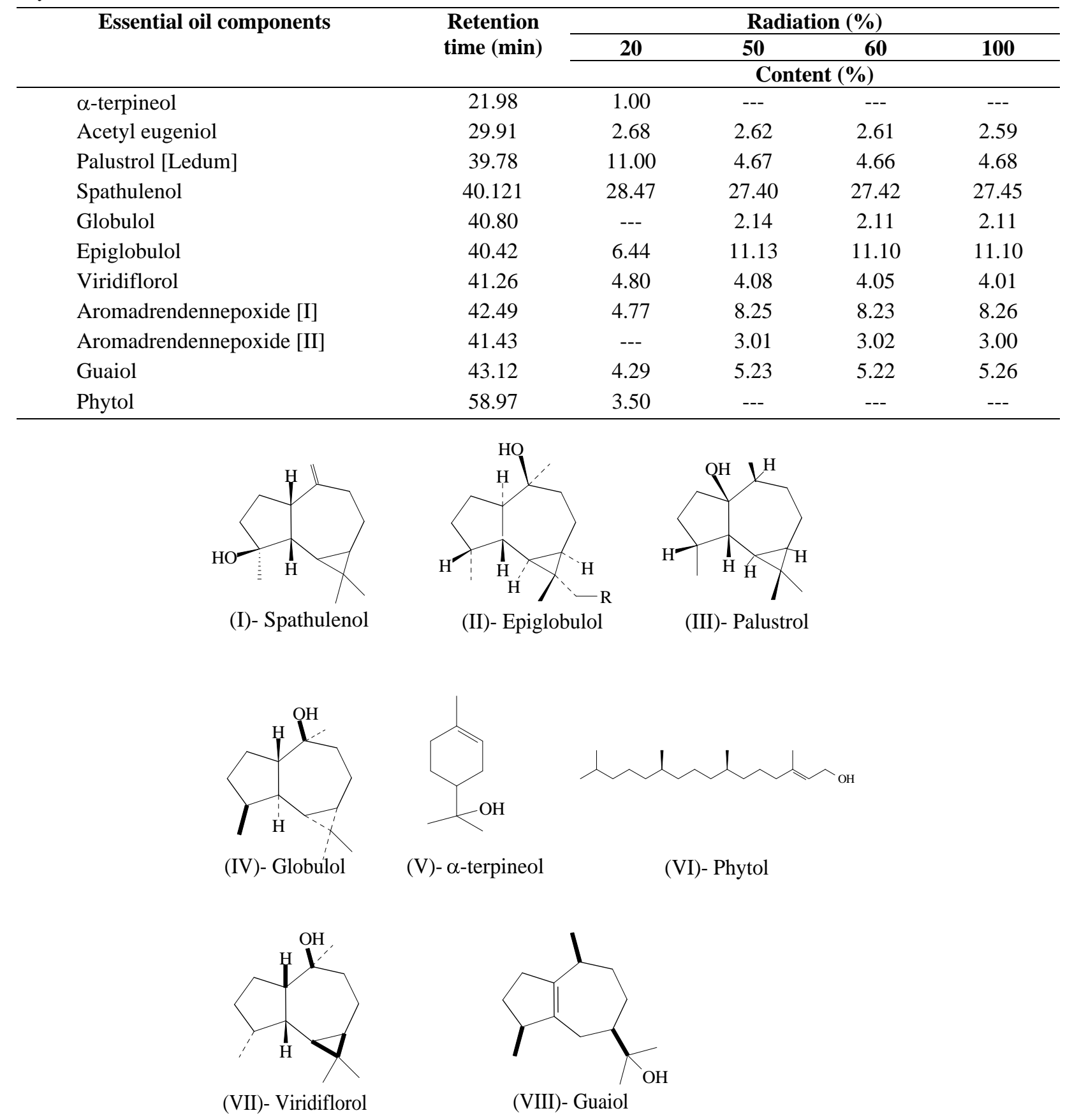

FIGURE 1 - Structural types of secondary metabolites in the essential oils from Baccharis trimera.

Ciênc. agrotec., Lavras, v. 30, n. 1, p. 52-57, jan./fev., 2006 


\section{CONCLUSIONS}

It was shown that carqueja responds positively to increases in irradiation with reduction in height, increase in the number of branches, nodes, diameter, accumulation of the aerial and underground biomasses, an increasing trend in the essential oil percentage and a considerable increase in the yield per plant. Therefore, the results obtained in this work were satisfactory according to the initial objectives, suggesting that, in establishing a commercial cultivation with the goal of obtaining essential oil, carqueja plants should be grown in full sunshine in order to maximize the essential oil yield.

\section{REFERENCES}

AUKEN, O. W. V.; BUSH, J. K. Influence of light levels, soil nutrients, and competition on seedling growth of Baccharis neglecta (Asteraceae). Bulletin of the Torrey Botanical Club, [S.1.], v. 117, n. 4, p. 438-444, 1990.

FAINI, F.; LABBE, C.; COLL, J. Seasonal changes in chemical composition of epicuticular waxes from the leaves of Baccharis linearis. Biochemical Systematics and Ecology, Oxford, v. 27, n. 7, p. 673-679, Oct. 1999.

GENE, R. M.; CARTAÑÁ, C.; ADZET, T.; MARÍN, E.; PARELLA, T.; CAÑIGUERAL, S. Anti-inflamatory and analgesic activity of Baccharis trimera: identification of active constituents. Planta Medica, Stuttgart, v. 62, n. 3, p. 232-235, June 1996.

JAKUPOVIC, J.; SCHUSTER, A.; GANZER, U.; BOHLMANN, F.; BOLDT, P. E. Sequi and diterpenes fron Baccharis species. Phytochemistry, Oxford, v. 29, n. 7, p. 2217-2222, 1990.

LETCHAMO, W.; GOSSELIN, A. Effects of supplemental lighting and soil water levels on growth, essential oil contend and composition of two thyme (Thymus vulgaris $L$ ) clonal selections. Canadian Journal of Plant Science, Ottawa, v. 75, n. 1, p. 231-238, Jan. 1995.

LETCHAMO, W.; GOSSELIN, A. Transpiration, essential oil glands, epicuticular wax and morphology of Thymus vulgaris are influenced by light intensity and water supply. Journal of Horticultural Science, Ashford, v. 71, n. 1, p. 123-134, Jan. 1996.

LETCHAMO, W.; MARQUARD, R.; HOLZL, J.; GOSSELIN, A. Effects of supply and light intensity on growth and essential oil of two Thymus vulgaris selections. Angewandte Botanik, Berlin, v. 68, n. 3/4, p. 83-88, Oct. 1994.
LOAYZA, I.; ABUJDER, R.; ARANDA, J.; JAKUPOVIC, G.; COLLIN, H.; DESLAURIERS, JEAN, F. I. Essential oils of Baccharis salicifolia, B. latifolia and B. dracunculifolia. Phytochemistry, Oxford, v. 38, n. 2, p. 381-389, Jan. 1995.

NAVES, V. L. Crescimento, distribuição de matéria seca, concentração de clorofilas e comportamento estomático de mudas de três espécies florestais submetidas a diferentes níveis de radiação fotossinteticamente ativa. 1993. 76 f. Dissertação (Mestrado) - Escola Superior de Agricultura de Lavras, Lavras, 1993.

QUEIROGA, C. L.; FERRACINE, V.; MARSAIOLI, A. J. Three new oxigenated cadinanes from Baccharis species. Phytochemistry, Oxford, v. 42, n. 4, p. 1097-1103, July 1996.

SILVA, J. B.; GROTTA, A. S. Anatomia e óleo essencial de Baccharis retusa D.C. Revista de Farmácia e Bioquímica da Universidade de São Paulo, São Paulo, v. 9, n. 2, p. 321326, 1971.

SIQUEIRA, N. C. S.; SILVA, G. A. A. B.; ALICE, C. B.; NITSCHKE, M. Análise comparativa dos óleos essenciais de Baccharis articulata (Lam.) Pers. e Baccharis trimera (Less.) DC (Compositae), espécies espontâneas no Rio Grande do Sul. Revista Brasileira de Farmácia, Rio de Janeiro, v. 4, n. 1, p. 36-39, 1985.

SUTTISRI, R.; KINGHORN, A. D.; WRIGHT, A. D.; STICHER, O. Neo-clerodane diterpenoids and other constituents from Baccharis genistelloides. Phytochemistry, Oxford, v. 35, n. 2, p. 443-446, Jan. 1994.

TAIZ, L.; ZEIGER, E. Plant physiology. 2. ed. Redwood City: The Benjamin, 1998. 792 p.

VENTRELLA, M. C.; MING, L. C. Produção de matéria seca e óleo essencial em folhas de erva-cidreira sob diferentes níveis de sombreamento e épocas de colheita. Horticultura Brasileira, Brasília, v. 18, p. 972-974, 2000. Suplemento.

YAMAURA, T.; TANAKA, S.; TABATA, M. Lightdependent formation of glandular trichomes and monoterpenes in thyme seedlings. Phytochemistry, Oxford, v. 28, n. 3, p. 741-744, 1989.

ZUNINO, M. P.; NEWTON, M. N.; MAESTRI, D. M.; ZYGADLO, J. A. Essential oils of three Baccharis species. Planta Medica, Stuttgart, v. 64, n. 1, p. 86-87, Feb. 1998. 